\title{
Analysis of ADAM9 regulation and function in vestibular schwannoma primary cells
}

\author{
Anja Nattmann ${ }^{1 \dagger}$, Maria Breun ${ }^{1 * \dagger}$, Camelia M. Monoranu², Cordula Matthies ${ }^{1}$, Ralf-Ingo Ernestus ${ }^{1}$, Mario Löhr ${ }^{1}$ \\ and Carsten Hagemann ${ }^{1}$
}

\begin{abstract}
Objective: Recently, we described a disintegrin and metalloproteinase 9 (ADAM9) overexpression by Schwann cells of vestibular schwannoma (VS) and suggested that it might be a marker for VS tumor growth and invasiveness. This research note provides additional data utilizing a small cohort of VS primary cultures and tissue samples. We examined whether reconstitution of Merlin expression in VS cells regulates ADAM9 protein expression and performed lentiviral ADAM9 knock down to investigate possible effects on VS cells numbers. Moreover, the co-localization of ADAM9 and Integrins a6 and a2 $\beta 1$, respectively, was examined by immunofluorescence double staining.

Results: ADAM9 expression was not regulated by Merlin in VS. However, ADAM9 knock down led to 58\% reduction in cell numbers in VS primary cell cultures $(p<0.0001)$. While ADAM9 and Integrin a $2 \beta 1$ were co-localized in only $22 \%$ (2 of 9) of VS, ADAM9 and Integrin a6 were co-localized in 91\% (10 of 11) of VS. Therefore, we provide first observations on possible regulatory functions of ADAM9 expression in VS.
\end{abstract}

Keywords: Vestibular schwannoma, Pathogenesis, ADAM9, Knock down, Integrin, Immunofluorescence double staining, Merlin, Primary cell culture

\section{Introduction}

Vestibular schwannoma (VS) are benign tumors emerging from Schwann cells of the vestibular part of the $8^{\text {th }}$ cranial nerve [1]. Their hallmark mutation is loss of Merlin function, which is a 4.1 protein/ezrin/radixin/ moesin protein (FERM) and acts as a tumor suppressor protein inhibiting Schwann cell growth by connecting the cytoskeleton with the cell membrane. It is activated by the cells' attachment to the extracellular matrix (ECM) and intercellular adhesion [2]. A disintegrin and metalloproteinase 9 (ADAM9) is involved in tumor growth and invasion by liberating membrane-bound proteins by an enzymatic modification called "shedding" [3]. Its proteolytic activity also releases cytokines and growth factors and it modifies the ECM by interacting with integrins [4]. In previous experiments we showed an 8.8 times higher ADAM9 mRNA-expression in VS compared to healthy vestibular nerves and suggested that ADAM9 inhibition may be of significance for VS pathogenesis and potential medical treatment [5]. Furthermore, we discussed whether ADAM9 might interact with the VS cell-matrix [5].

This research note builds on our recent findings. We hypothesized that alteration of Merlin expression could regulate ADAM9 protein expression and that ADAM9 plays a role in VS cell proliferation. Finally, we investigated co-localization of ADAM9 with Integrin $\alpha 6$ and Integrin $\alpha 2 \beta 1$, respectively, aiming to get a rough idea on putative regulatory protein interactions in VS.

\footnotetext{
*Correspondence: Breun_M@ukw.de

${ }^{\dagger}$ Anja Nattmann and Maria Breun contributed equally to this paper

1 Department of Neurosurgery, University Hospital Würzburg,

Josef-Schneider-Str. 11, 97080 Würzburg, Germany

Full list of author information is available at the end of the article
}

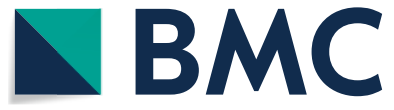

(c) The Author(s) 2020. This article is licensed under a Creative Commons Attribution 4.0 International License, which permits use, sharing, adaptation, distribution and reproduction in any medium or format, as long as you give appropriate credit to the original author(s) and the source, provide a link to the Creative Commons licence, and indicate if changes were made. The images or other third party material in this article are included in the article's Creative Commons licence, unless indicated otherwise in a credit line to the material. If material is not included in the article's Creative Commons licence and your intended use is not permitted by statutory regulation or exceeds the permitted use, you will need to obtain permission directly from the copyright holder. To view a copy of this licence, visit http://creativecommons.org/licenses/by/4.0/. The Creative Commons Public Domain Dedication waiver (http://creativecommons.org/publicdomain/zero/1.0/) applies to the data made available in this article, unless otherwise stated in a credit line to the data. 


\section{Material and methods}

\section{Tissue samples and cell culture}

Tissue of 24 VS, surgically resected in the Department of Neurosurgery of the University Hospital Würzburg, was collected from January 2018 until July 2019. Half of each sample was embedded in paraffin for immunohistochemistry, the other half was processed for primary cell culture as described elsewhere [6] and briefly outlined in Additional file 1.

\section{Merlin overexpression}

95,000 cells per well of the primary cell cultures were treated with $2 \mathrm{ml}$ VS-medium (see Additional file 1) containing $8 \mu \mathrm{g} / \mathrm{ml}$ protamine (Sigma, Munich, Germany) and $100 \mu \mathrm{l}$ NF2 transcript variant 1 (NM_000268) Human mGFP Tagged ORF Clone Particle RC205883L2 (OriGene, Rockville, MD, USA) and incubated for 2 days. The medium was replaced by $2 \mathrm{ml}$ fresh VS-medium, cells were photographically documented and lysed as described below.

\section{ADAM9 knock down}

Cells were prepared as described above, but $57 \mu$ l ADAM9 Human shRNA Lentiviral Particle TL314947VB (Locus ID 8754) (knock down) or $120 \mu \mathrm{l}$ Lenti-shRNA Control Particles TR30021V (scrambled control) (OriGene, Rockville, MD, USA) were added. After 3 days the medium was replaced by $2 \mathrm{ml}$ VSmedium and $24 \mathrm{~h}$ later by $2 \mathrm{ml}$ VS-medium containing $1 \mu \mathrm{g} / \mathrm{ml}$ puromycin (Gibco, Carlsbad, CA, USA), which was exchanged every 2 days by DMEM. At day 11 five fields of view of each well were photographed through the $10 \times$ magnifying objective of the DMI $3000 \mathrm{~B}$ fluorescence microscope and the DFC 450C camera (Leica, Wetzlar, Germany) in bright field with $35 \mathrm{~ms}$ exposure time and for green fluorescence using filter L5 ET and an exposure time of $900 \mathrm{~ms}$. Cells were counted after importing the photographed fields of view to the program ImageJ by applying the tool "multi point" (National Institutes of Health $(\mathrm{NIH})$, Bethesda, MD, USA; https://imagej.nih.gov/ij/).

\section{Western-blot}

After washing the cells twice with phosphate buffered saline (PBS; Biochrom, Berlin, Germany), they were lysed with $100 \mu \mathrm{l}$ lysis buffer $[10 \mathrm{mM}$ Tris-HCl $\mathrm{pH}$ 7.4, $150 \mathrm{mM} \mathrm{NaCl}, 1 \mathrm{mM}$ ethylenediaminetetraacetic acid (EDTA), $1 \mathrm{mM}$ ethylene glycerol-bis ( $\beta$-aminoethylether)- $\mathrm{N}, \mathrm{N}, \mathrm{N}^{\prime}, \mathrm{N}^{\prime}$-tetraacetic acid (EGTA), 1\% Triton X-100, 0.5\% IGEPAL CA-630, $1 \mathrm{mM}$ phenylmethanesulfonylfluoride (PMSF), $10 \mu \mathrm{g} / \mathrm{ml} \mathrm{leu-}$ peptin and $23 \mu \mathrm{g} / \mathrm{ml}$ aprotinin (all from Sigma, Munich,
Germany)]. The extracted protein was measured with the Qubit 2.0 Fluorometer (Thermo Fisher Scientific, Waltham, MA, USA). $0.3 \mu \mathrm{g}$ total protein was loaded to a polyacrylamid gel, electrophoresis was performed as described [7] and the gel blotted for $7 \mathrm{~min}$ using the iBlot system (Thermo Fisher Scientific, Waltham, MA, USA) set to program 3. The membrane was blocked in TBST (Sigma, Munich, Germany) containing 5\% non-fat milk powder (Roth, Karlsruhe, Germany) and probed with antibodies as described previously [7]. Antibodies NF2 B-12 sc-55575 (Santa Cruz Biotechnology, Dallas, TX, USA), ADAM9 ab186833 (Abcam, Cambridge, UK), and anti- $\gamma$-tubulin T6557 (Sigma, Munich, Germany) were utilized diluted in TBST at $1: 200,1: 1500$, and 1:5000, respectively. Goat anti-rabbit IgG H\&L (HRP) ab6721 (Abcam, Cambridge, UK), anti-mouse IgG HRP NA931 (GE Healthcare, Freiburg, Germany) and anti-mouse m-IgGk BP-HRP sc516102 (Santa Cruz Biotechnology, Dallas, TX, USA) antibodies were used as secondary antibodies at a 1:1000 dilution in TBST. The ECL Western Blotting Analysis System (Amersham, Freiburg, Germany) was used to visualize the antibody labeled proteins.

\section{Immunofluorescence double-staining}

Immunofluorescence staining of $3 \mu \mathrm{m}$ thick formalinfixed paraffin sections has been described previously [7, 8]. However, blocking with $10 \%$ goat serum (Life Technologies, Waltham, MA, USA) was performed for $2 \mathrm{~h}$ prior to an incubation of the slides with antibody dilution buffer (DCS, Jena, Germany) containing antibodies antiADAM9 ab186833 (1:100) in combination with anti-Integrin $\alpha 2 \beta 1$ [16B4] ab30483 (1:50) or anti-Integrin $\alpha 6$ [MP 4F10] ab20142 (1:50) (all from Abcam, Cambridge, UK) at $4{ }^{\circ} \mathrm{C}$ overnight. Protein expression was visualized by $1 \mathrm{~h}$ incubation using Goat anti-Rabbit IgG $(\mathrm{H}+\mathrm{L})$ Highly Cross-Adsorbed Secondary Antibody (Alexa Fluor Plus 488 (A32732) and 555 (A32732); Thermo Fisher Scientific, Waltham, MA, USA), both diluted 1:400. Slides were mounted using Fluoroshield mounting medium, containing DAPI (Abcam, Cambridge, UK) and photographed with the Leica microscope DMI 3000B and the DFC 450C camera, using three different filters (Filtercubes A, L5 ET, and TXR ET) with exposure times of $77 \mathrm{~ms}, 2.5 \mathrm{~s}$ and $1.5 \mathrm{~s}$, respectively, at both 10 and $40 \times$ objective magnification. The percentage of positively stained tumors in relation to all stained tumors was calculated.

\section{Statistical analysis}

Statistical analysis was performed with GraphPad Prism 6 software (GraphPad Software, La Jolla, CA, USA) to determine significance using unpaired tests. $\mathrm{p}<0.05$ was considered to be statistically significant. 


\section{Results}

Without exception, high amounts of ADAM9 were detectable in all 24 VS (Fig. 1a). Since Merlin loss is a hallmark of VS development [9], we wondered whether the ADAM9 expression was due to lacking regulation by Merlin. Therefore, we restored Merlin expression by lentiviral transfection (Fig. 1b) and checked for any alteration in ADAM9 expression utilizing Western-blots (Fig. 1c). ADAM9 expression levels, however, did not significantly differ in cells with or without Merlin expression (Fig. 1d), ruling out Merlin-mediated ADAM9 regulation. Next, we asked whether ADAM9 expression might be involved in the proliferation of VS cells. Therefore, a lentiviral shRNA-mediated ADAM9 knock down was performed (Fig. 2a). The ADAM9 shRNA led to a threefold reduction of ADAM9 compared to scrambled control (band intensity normalized to $\gamma$-Tubulin expression 1.4 vs. 4.1, respectively) in a proof of principle experiment (Fig. 2b). While Merlin overexpression did not result in statistically significant reduced cell numbers in comparison to vector-transfected controls, ADAM9 knock down caused a significant $58 \%$ reduction of VS cell numbers in comparison to the scrambled controls $(\mathrm{p}<0.0001)$ and to
$18 \%$ reduction in comparison to Merlin overexpressing primary cells $(\mathrm{p}=0.0213)$ (Fig. 2c).

ADAM9 is a cell-matrix modifying enzyme, reported to interact with Integrin $\alpha 6 \beta 1$ and thereby regulating cellular motility [10]. This integrin is also expressed by VS cells [10] and therefore could be associated with ADAM9 in VS. Indeed, Integrin $\alpha 6$ expression could be found in 10 of 11 investigated VS (91\%) and was co-localized with ADAM9 (Fig. 3). This co-localization was mainly found in tumor tissue (Fig. 3a, b), near blood vessels (Fig. 3c) and enriched along the tumor capsule (Fig. 3e, f). In contrast, Integrin $\alpha 2 \beta 1$ was only weakly expressed in the analyzed VS (Fig. 3g, h). Strong expression with scattered ADAM9 co-localization was observed in merely two of 9 VS (22\%) (Fig. 3g).

\section{Discussion}

We were the first to describe ADAM9 overexpression in VS, suggesting it might be a marker for tumor growth and invasiveness [5]. However, our study was descriptive in nature and we only could speculate on ADAM9 regulation and function. Here, we performed first experiments to address these questions. We confirmed
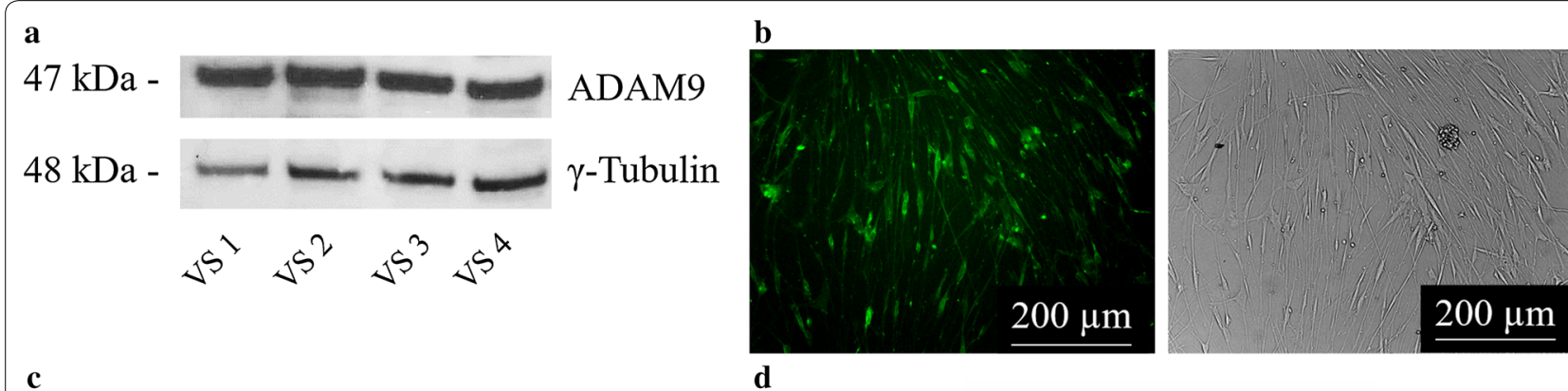

c
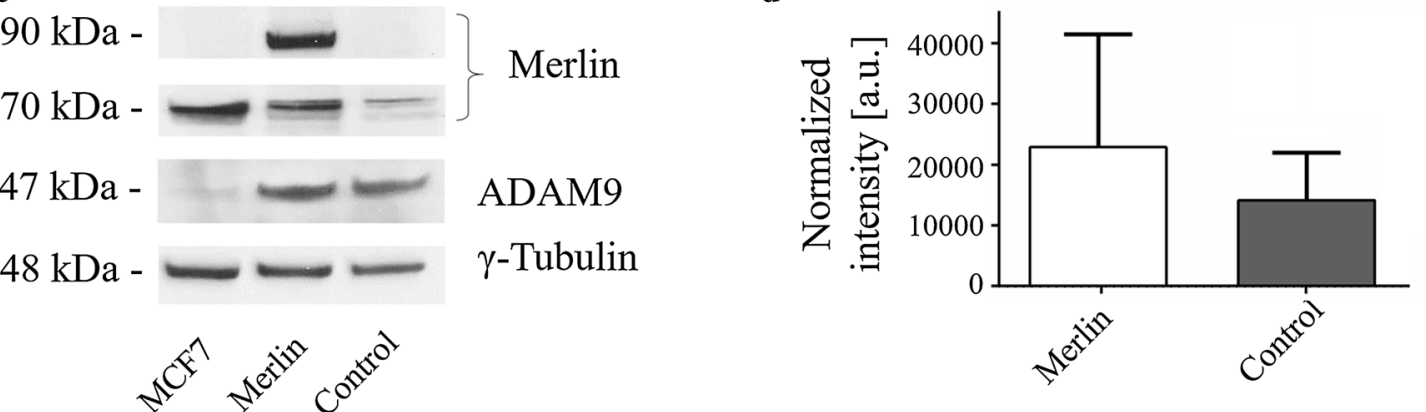

Fig. 1 ADAM9 was not regulated by Merlin in VS. a Western-blot of ADAM9 expression in four representative VS of $n=24$. $\mathbf{b}$ Merlin protein expression in VS primary cells after lentiviral transfection. The immunofluorescent images compare successfully transfected green fluorescent cells (left) with the same field of view showing all cells (right) to estimate the transfection rate. c Western-blot of MCF7 breast cancer cell-lysate (MCF7), suggested by the manufacturer of the Merlin antibody as positive control, VS primary cells transfected with Merlin (Merlin) and untransfected VS primary cells (Control). Cell lysates were loaded twice onto the same gel to avoid stripping of the blot, which then was cut into half for the incubation with Merlin and ADAM9 antibody, respectively. Shown is one representative experiment of $n=3$. $\gamma$-Tubulin served as loading control in all Western-blot experiments. Blots were cropped for better clarity. The full length blots are presented in Additional file 1, Fig. S1 and full length blots of the two additional experiments in Additional file 1, Fig. S2a. d Quantification of ADAM9 expression in Merlin overexpressing (Merlin) and untransfected VS primary cells (Control) as analyzed in (c) 

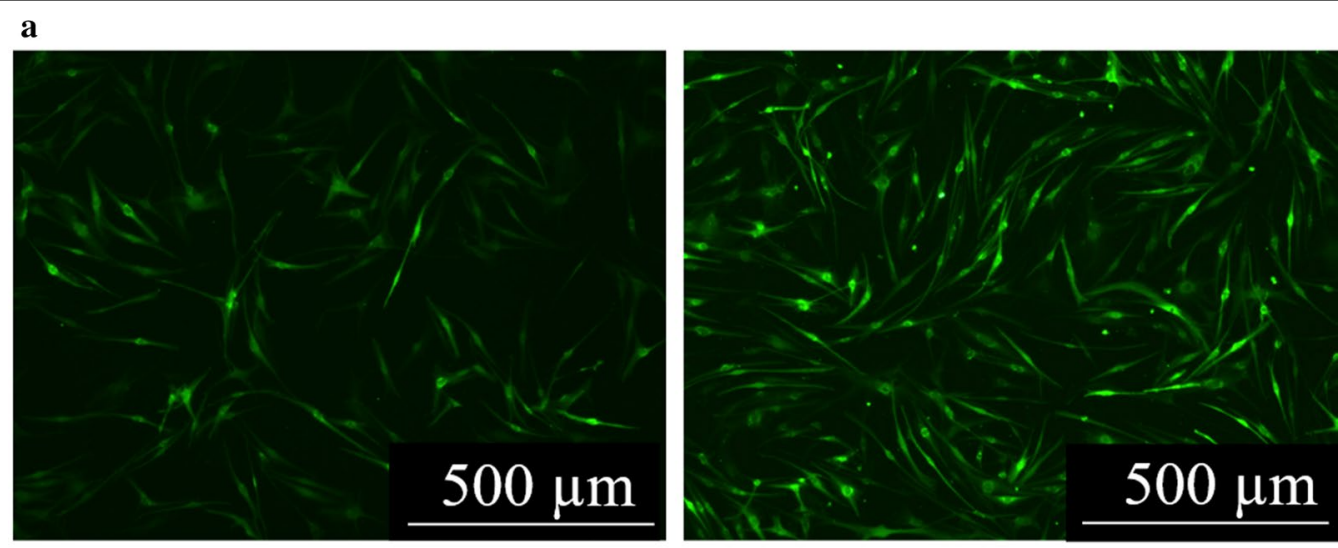

b

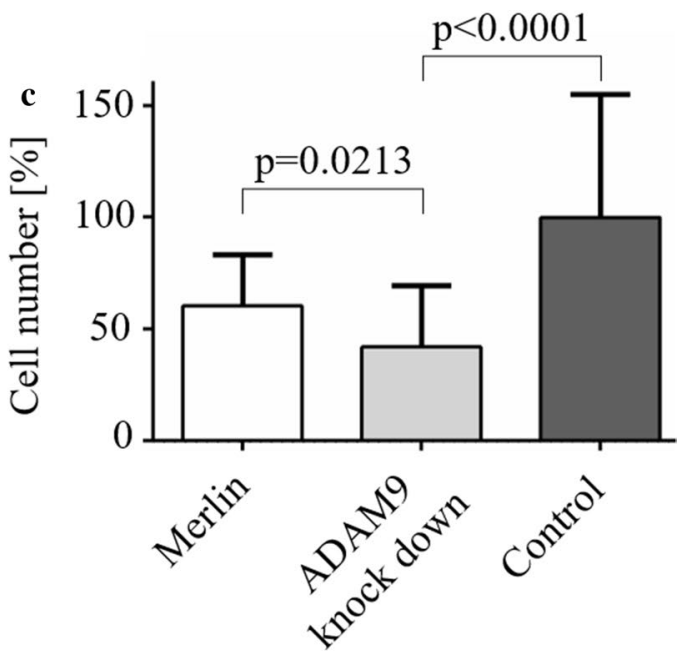

Fig. 2 ADAM9 was involved in controlling VS primary cell proliferation. a Lentiviral mediated shRNA knock down of ADAM9. Green fluorescent ADAM9 knock down (left) and scrambled transfected control cells (right). One representative experiment of $n=4$ is shown. $\mathbf{b}$ Proof of principle Western-blot of ADAM9 knock down, $n=1$. $\gamma$-Tubulin served as loading control. Blots were cropped for better clarity. The full length blots are presented in Additional file 1, Fig. S2b. c Quantification of cell numbers after Merlin overexpression (Merlin) and ADAM9 knock down

(See figure on next page.)

Fig. 3 Co-localization of ADAM9 with Integrin a6 and Integrin a2 $\beta 1$ in VS tumor samples. a-f Immunofluorescence double-staining of ADAM9 (red) and Integrin a6 (green). a, b Co-localization (yellow) was mainly found in tumor tissue and $\mathbf{c}$ near blood vessels (arrows). $\mathbf{d}$ One VS did not express any detectable Integrin a6. e, f Demonstrate enriched co-localization along the tumor capsule (arrows). $\mathbf{g}, \mathbf{h}$ Immunofluorescence double-staining of ADAM9 (red) and Integrin a2 $\beta 1$ (green). $\mathbf{g}$ Integrin a2 $\beta 1$ VS with ADAM9 co-localization. $\mathbf{h}$ Integrin a2 $\beta 1$ negative VS. DAPI= blue. Representative images of $n=20$. The split-channel images are provided in Additional file 1 Fig. S3

expression of ADAM9 in the analyzed VS, showed that Merlin overexpression does not regulate expression of the $47 \mathrm{kDa}$ ADAM9 isoform, but that an ADAM9 knock down resulted in reduced VS cell numbers. Furthermore, we demonstrated ADAM9 co-localization with Integrin $\alpha 6$ in $91 \%$ of the analyzed VS, but with Integrin $\alpha 2 \beta 1$ only in $22 \%$ of the cases.

Merlin modulates cell-cell interactions and cell migration. It is a tumor suppressor gene, with loss of function mutations in VS [11], leading to overexpression of
Neuregulin 1 (NDRG1), which in turn activates ERK- and AKT-signaling pathways in VS, promoting VS cell proliferation [12-14]. Since we observed overexpression of ADAM9 in VS, we wondered whether this may be due to the loss of Merlin in these cells and restored Merlin expression. However, our data suggest that there is no causal link between loss of Merlin and overexpression of at least the proteolytically-processed, membrane-bound $47 \mathrm{kDa}$ isoform of ADAM9 [3]. However, the knock down of ADAM9 led to a reduction of VS cell numbers. 

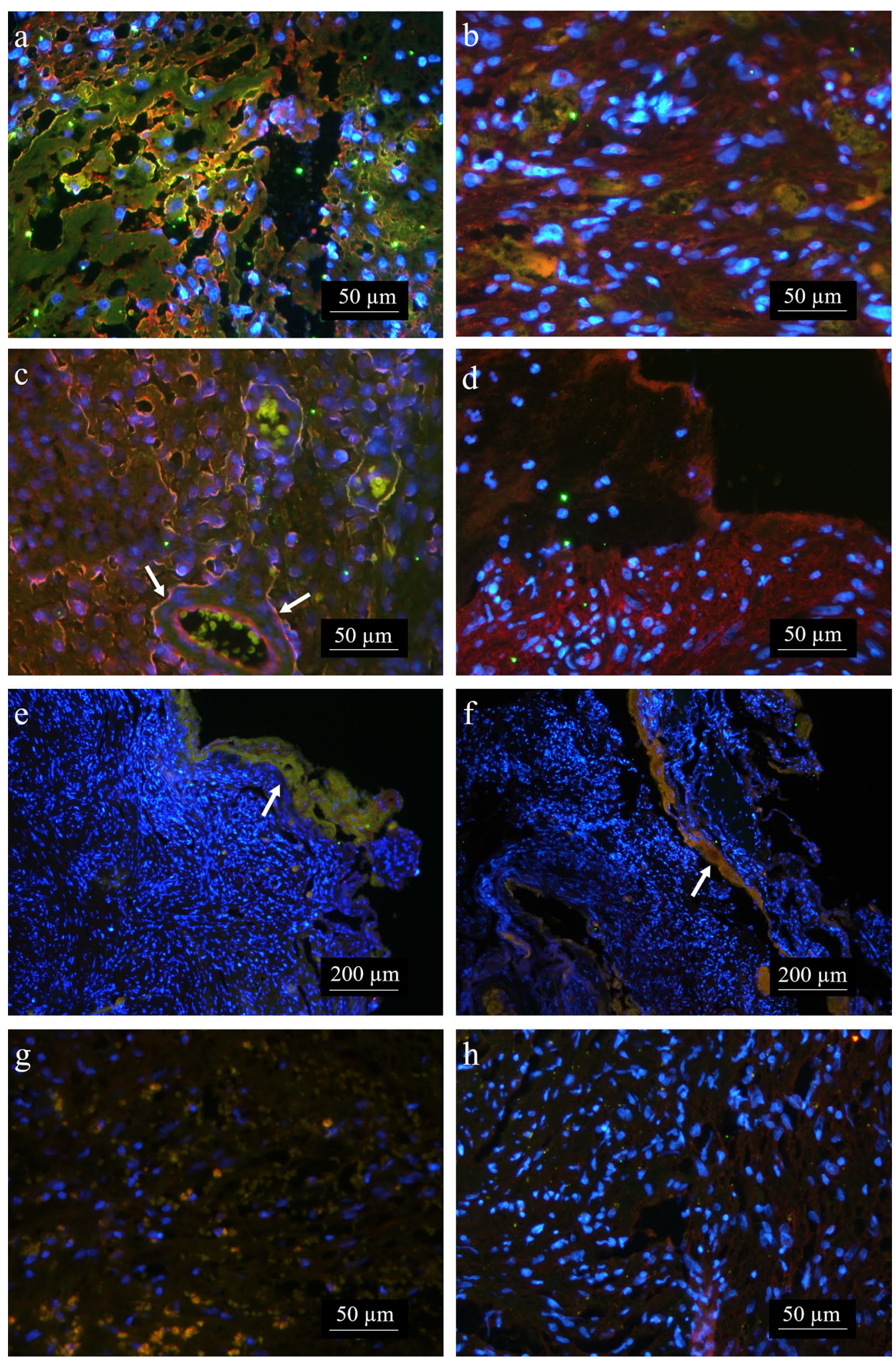
ADAM9 inhibition had already been shown to reduce migration and invasion of human glioma cell lines [15]. Therefore, our data might be a first hint that ADAM9 plays a similar role in VS and its expression might induce progression or possibly reduce cell death in these benign tumors.

ADAM9 is a cell membrane spanning protein connecting the cytoskeleton with the ECM or neighboring cells. Its cysteine-rich domain binds to proteoglycans and its disintegrin domain to integrins [3]. Metalloproteinases of the ADAM-family digest proteins of the ECM, allowing tumor cells to detach from the tissue and thereby promoting their migration and invasion $[3,16]$ Thus, highest ADAM9 expression could be detected in areas of liver metastases with high invasive growth [3]. Integrins mediate attachment of cells to the basal lamina [17]. Integrin $\alpha 6$ and Integrin $\alpha 2 \beta 1$ are both known substrates of ADAM9. Interaction of ADAM9 and Integrin $\alpha 2 \beta 1$ has been described for liver metastases [3] and of ADAM9 and Integrin $\alpha 6 \beta 1$ for fibroblasts [10]. However, their association had not yet been shown for VS. Since we found co-localization of ADAM9 and Integrin $\alpha 2 \beta 1$ in only $22 \%$ of the analyzed VS, we conclude that this is not the main substrate of ADAM9 in VS. On the other hand, Integrin $\alpha 6$ is detectable in Schwann cells [18]. Its precursor has higher expression levels in VS cells in comparison to Schwann cells [19] and we found colocalization in $91 \%$ of the VS with highest levels in tumor tissue and near blood vessels. ADAM9 knock-out mice display a significant reduction of retinal neovascularization, whereas ADAM9 was highly expressed in pathological retinal blood vessels of wild type mice [20]. It has been suggested that hypoxia induces ADAM9 expression and this enhanced expression in turn leads to release of pro-angiogenic factors [20]. Our data may support such assumption and could indicate that VS may require neoangiogenesis for their growth, although they are generally considered to be weakly vascularized tumors [21].

Our new data supplement our previous observations on ADAM9 expression in VS, are a first glimpse on possible regulatory functions and provide a rationale for more in-depth future investigations.

\section{Limitations}

VS are slowly growing, benign tumors. Thus, it is a challenge to establish primary cell cultures [6] and even more difficult to achieve high transfection rates. For this reason, only a small number of experiments could be performed for protein knock down and overexpression, limiting generalizability of these experiments. Several ADAM9 isoforms have been described [3, $22,23]$. However, the antibody used in this study was specific for the $47 \mathrm{kDa}$ isoform only. Therefore, we cannot conclude on a possible Merlin mediated regulation of other ADAM9 isoforms. The immunofluorescence double staining indicates co-localization of ADAM9 and Integrin $\alpha 6$ or $\alpha 2 \beta 1$, which does not necessarily mean that there is direct protein-protein interaction.

\section{Supplementary information}

Supplementary information accompanies this paper at https://doi. org/10.1186/s13104-020-05378-7.

Additional file 1: Additional details pertaining to material and methods. Details of cell culture. Figure S1. Unaltered full-length Western-blots of ADAM9, Merlin and $\mathrm{Y}$-Tubulin protein expression in VS and VS primary cells from Fig. 1. Figure S2. Unaltered full-length Western-blots of Merlin, ADAM9 and $\gamma$-Tubulin protein expression in VS primary cells. Figure S3. Split-channel presentation of ADAM9 co-localization with Integrin a6 and Integrin a $2 \beta 1$ in VS tumor samples as shown in Fig. 3

\section{Abbreviations}

ADAM9: A disintegrin and metalloproteinase 9; DAPI: 4',6-Diamidin-2-phenylindol; DMEM: Dulbeccos's modified Eagle's medium; ECM: Extracellular matrix; EDTA: Ethylenediaminetetraacetic acid; EGTA: Ethylene glycerol-bis ( $\beta$-aminoethylether)- $\mathrm{N}, \mathrm{N}, \mathrm{N}^{\prime}, \mathrm{N}^{\prime}$-tetraacetic acid; FERM: 4.1 Protein/ezrin/radixin/ moesin protein; IBMX: 3-Isobutyl-1-methylxanthin; NDRG1: Neuregulin 1; PBS: Phosphate buffered saline; PMSF: Phenylmethanesulfonylfluoride; TBST: Trisbuffered saline Tween 20; VS: Vestibular schwannoma.

\section{Acknowledgements}

We thank Siglinde Kühnel, Elisabeth Karl and Katharina Grüning (Department of Neurosurgery, University Hospital Würzburg, Germany) for excellent technical assistance. We are grateful to Ellaine Salvador (Department of Neurosurgery, University Hospital Würzburg, Germany) for language editing.

\section{Authors' contributions}

All authors contributed to the study conception and design. The study was supervised by MB, ML and $\mathrm{CH}$. Samples were collected by MB and CM, experiments performed by $A N$ and data analyzed by $A N, M B$ and $C H$. CMM analyzed the histological tumor tissue samples. $\mathrm{AN}$ and $\mathrm{CH}$ wrote the draft of the manuscript which was substantially revised by MB, CM, R-IE and ML. All authors read and approved the final manuscript. $\mathrm{AN}$ and $\mathrm{MB}$ contributed equally to this paper. MB is the corresponding author.

\section{Funding}

This work was funded by the Interdisciplinary Center of Clinical Research (IZKF) Würzburg (Z-2/72). This publication was supported by the Open Access Publication Fund of the University of Würzburg.

\section{Availability of data and material}

The datasets generated and analyzed during the current study are included in this published article and its additional information files. Raw data are available from the corresponding author on reasonable request.

\section{Ethics approval and consent to participate}

The patients were treated at the Department of Neurosurgery, University Hospital Würzburg. They gave their written informed consent for participating in the study, which was conducted in accordance with the declaration of Helsinki and as approved by the institutional review board of the University of Würzburg in July 2016 (\#145/16)

Consent for publication Not applicable.

Competing interests

The authors declare that they have no competing interests. 


\begin{abstract}
Author details
${ }^{1}$ Department of Neurosurgery, University Hospital Würzburg, Josef-Schneider-Str. 11, 97080 Würzburg, Germany. ${ }^{2}$ Department of Neuropathology, Institute of Pathology, University of Würzburg, 97080 Würzburg, Germany.
\end{abstract}

\section{Received: 7 September 2020 Accepted: 5 November 2020}

Published online: 11 November 2020

\section{References}

1. Tatagiba M, Ebner FH. Kleinhirnbrückenwinkelprozesse. In: Moskopp D, Wassmann H, editors. Neurochirurgie. 2nd ed. Stuttgart: Schattauer $\mathrm{GmbH} ; 2015$. p. 596-608.

2. Cooper J, Giancotti FG. Molecular insights into NF2/Merlin tumor suppressor function. FEBS Lett. 2014;588:2743-52. https://doi.org/10.1016/j. febslet.2014.04.001.

3. Klein T, Bischoff R. Active metalloproteases of the A disintegrin and metalloprotease (ADAM) family: biological function and structure. J Proteome Res. 2011;10:17-33. https://doi.org/10.1021/pr100556z.

4. Huovila A-PJ, Turner AJ, Pelto-Huikko M, Kärkkäinen I, Ortiz RM. Shedding light on ADAM metalloproteinases. Trends Biochem Sci. 2005;30:413-22. https://doi.org/10.1016/j.tibs.2005.05.006.

5. Breun M, Schwerdtfeger A, Martellotta DD, Kessler AF, Monoranu CM, Matthies C, et al. ADAM9: a novel player in vestibular schwannoma pathogenesis. Oncol Lett. 2020;19:1856-64. https://doi.org/10.3892/ ol.2020.11299.

6. Breun M, Martellotta DD, Leberle A, Nietzer S, Baur F, Ernestus R-I, et al. $3 \mathrm{D}$ in vitro test system for vestibular schwannoma. J Neurosci Methods. 2020;336:108633. https://doi.org/10.1016/j.jneumeth.2020.108633.

7. Breun M, Schwerdtfeger A, Martellotta DD, Kessler AF, Perez JM, Monoranu CM, et al. CXCR4: a new player in vestibular schwannoma pathogenesis. Oncotarget. 2018;9:9940-50. https://doi.org/10.18632/oncotarget .24119 .

8. Feldheim J, Kessler AF, Schmitt D, Salvador E, Monoranu CM, Feldheim JJ, et al. Ribosomal protein S27/metallopanstimulin-1 (RPS27) in glioma-a new disease biomarker? Cancers (Basel). 2020. https://doi.org/10.3390/ cancers 12051085

9. Hanemann CO. Magic but treatable? Tumours due to loss of Merlin. Brain. 2008;131:606-15. https://doi.org/10.1093/brain/awm249.

10. Nath D, Slocombe PM, Webster A, Stephens PE, Docherty AJ, Murphy G. Meltrin $\gamma(A D A M-9)$ mediates cellular adhesion through a6 31 integrin, leading to a marked induction of fibroblast cell motility. J Cell Sci. 2000;113:2319-28.

11. Sughrue ME, Yeung AH, Rutkowski MJ, Cheung SW, Parsa AT. Molecular biology of familial and sporadic vestibular schwannomas: implications for novel therapeutics. J Neurosurg. 2011;114:359-66. https://doi. org/10.3171/2009.10.JNS091135.
12. Ammoun S, Flaiz C, Ristic N, Schuldt J, Hanemann CO. Dissecting and targeting the growth factor-dependent and growth factor-independent extracellular signal-regulated kinase pathway in human schwannoma. Cancer Res. 2008;68:5236-45. https://doi.org/10.1158/0008-5472. CAN-07-5849.

13. Carroll SL. Molecular mechanisms promoting the pathogenesis of Schwann cell neoplasms. Acta Neuropathol. 2012;123:321-48. https://doi org/10.1007/s00401-011-0928-6.

14. Schulze KMM, Hanemann CO, Müller HW, Hanenberg H. Transduction of wild-type merlin into human schwannoma cells decreases schwannoma cell growth and induces apoptosis. Hum Mol Genet. 2002;11:69-76. https //doi.org/10.1093/hmg/11.1.69.

15. Huang C-F, Yang S-F, Chiou H-L, Hsu W-H, Hsu J-C, Liu C-J, et al. Licochalcone $A$ inhibits the invasive potential of human glioma cells by targeting the MEK/ERK and ADAM9 signaling pathways. Food Funct. 2018;9:6196204. https://doi.org/10.1039/c8fo01643g.

16. Duffy MJ, McKiernan E, O'Donovan N, McGowan PM. Role of ADAMs in cancer formation and progression. Clin Cancer Res. 2009;15:1140-4. https ://doi.org/10.1158/1078-0432.CCR-08-1585.

17. Lüllmann-Rauch R. Binde- und Stützgewebe. In: Lüllmann-Rauch R, editor. Taschenlehrbuch Histologie. 4th ed. Stuttgart: Thieme; 2012. p. 119-73.

18. Hogervorst F, Admiraal LG, Niessen C, Kuikman I, Janssen H, Daams H, et al. Biochemical characterization and tissue distribution of the $A$ and $B$ variants of the integrin a6 subunit. J Cell Biol. 1993;121:179-91. https:// doi.org/10.1083/jcb.121.1.179.

19. Hanemann CO, Bartelt-Kirbach B, Diebold R, Kämpchen K, Langmesser S, Utermark T. Differential gene expression between human schwannoma and control Schwann cells. Neuropathol Appl Neurobiol. 2006:32:605-14. https://doi.org/10.1111/j.1365-2990.2006.00769.x.

20. Guaiquil V, Swendeman S, Yoshida T, Chavala S, Campochiaro PA, Blobel CP. ADAM9 is involved in pathological retinal neovascularization. Mol Cell Biol. 2009;29:2694-703. https://doi.org/10.1128/MCB.01460-08.

21. Brieger J, Bedavanija A, Lehr H-A, Maurer J, Mann WJ. Expression of angiogenic growth factors in acoustic neurinoma. Acta Otolaryngol. 2003;123:1040-5. https://doi.org/10.1080/00016480310005101.

22. Mazzocca A, Coppari R, de Franco R, Cho J-Y, Libermann TA, Pinzani M, et al. A secreted form of ADAM9 promotes carcinoma invasion through tumor-stromal interactions. Cancer Res. 2005;65:4728-38. https://doi. org/10.1158/0008-5472.CAN-04-4449.

23. Fry $\mathrm{J}$, Toker A. Secreted and membrane-bound isoforms of protease ADAM9 have opposing effects on breast cancer cell migration. Cancer Res. 2010;70:8187-98. https://doi.org/10.1158/0008-5472.CAN-09-4231.

\section{Publisher's Note}

Springer Nature remains neutral with regard to jurisdictional claims in published maps and institutional affiliations.
Ready to submit your research? Choose BMC and benefit from:

- fast, convenient online submission

- thorough peer review by experienced researchers in your field

- rapid publication on acceptance

- support for research data, including large and complex data types

- gold Open Access which fosters wider collaboration and increased citations

- maximum visibility for your research: over 100M website views per year

At BMC, research is always in progress.

Learn more biomedcentral.com/submissions 